\title{
Disparity in the Hospitals Utilization among Regions in Indonesia
}

\author{
Trias Mahmudiono* (iD, Agung Dwi Laksono ${ }^{2,3}$ (D) \\ ${ }^{1}$ Department of Nutrition, Faculty of Public Health, Universitas Airlangga, Surabaya, Indonesia; ${ }^{2}$ Indonesia Agency for Health \\ Research and Development, Ministry of Health, Jakarta, Indonesia; ${ }^{3}$ Doctorate Degree Program in Public Health, Faculty of \\ Public Health, Universitas Airlangga, Surabaya, Indonesia
}

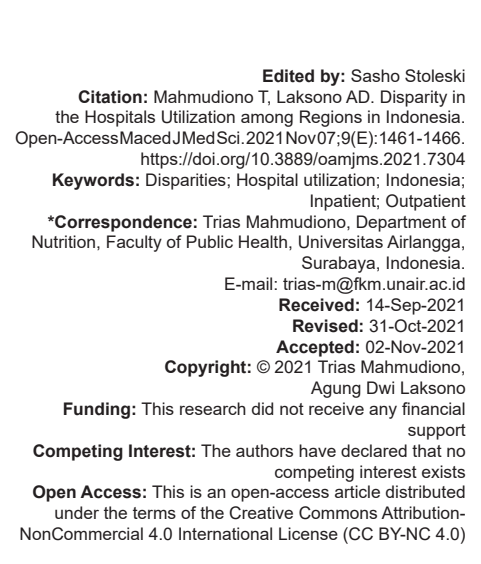

Introduction

Indonesia is the fourth most populous country in the world with over 260 thousand citizens. Its territory stretches over 1000 miles from north to south and over more than 3100 miles from east to west, making it the largest archipelago in the world. These challenging conditions along with lack of infrastructure posed economic and health disparity among its regions. Disparities as a result of this development also have an impact on the accessibility of health-care facilities. Regions with good economic movements tend to have good accessibility to health-care facilities [1]. For this reason, reducing disparity to achieve universal health services is the goal of health planners and policy-makers [2].

Several studies on the disparity in the use of health services take the focus of urban-rural. The results found significant differences between urban and rural [2], [3], [4], [5], [6], [7], [8]. Based on the results of these studies, it was assumed that if one region has many urban areas, then it has better utilization of health services compared to areas dominated by rural areas.

The characteristics of Indonesian regions are unique. This is due to the division of regions that refer to the main islands. This condition is motivated by Indonesia's geographical conditions in the form of islands. Indonesia consists of at least 16,056 islands that have been verified by the United Nations Group of Experts on Geographical Names from the United Nation. This number is part of the total of 17,504 islands recognized by Indonesia.

From the consumer perspective, hospital utilization is an indicator to assess the quality of health services in a particular area [9], [10], although this still has to be combined with regulations regarding the technical standards of a hospital. On the other hand, from the perspective of basic health services, the utilization of hospital services is also a benchmark for the success of a health-care referral system [11]. The purpose of this article is to report on the disparity in hospital utilization between regions in Indonesia.

\section{Materials and Methods}

Data source for this study was the Basic Health Survey (Riskesdas) in 2013 [12]. Riskesdas was a national scale survey carried out by the Indonesian Ministry of 
Health's Research and Development Agency. Hospital utilization includes government and private hospitals. The region grouping was based on geographical location.

The unit of analysis in this study was Indonesian population aged 15 years and over. At that age, it was assumed that the respondent has grown up and able to their own decision to access hospital services or not. The sample size analyzed in this paper was 722,329 respondents.

Hospital utilization was defined as public access to the hospital, whether it was outpatient or inpatient care in the hospital. Outpatient care was services in the hospital that did not require staying overnight in the hospital or hospital service that was used intermittently in the past month of the survey, while hospitalization or inpatients care was hospital service that required staying overnight in the hospital in the past year. The decision to use this time limit for recall was based on the assumption that the respondent believed to be able to remember accessing the outpatient and inpatient care in the hospital very well.

Chi-square test was used to test dichotomy variables and t-tests were performed for analyzing the difference among continuous variables. These tests were employed to assess the hypothesis that there was significant regional difference in the access of health care in Indonesia. Estimation using multinomial logistic regression test was used to study the disparity between regions in hospital utilization. IBM SPSS Statistic 21 was used for all test and data analysis.

\section{Results}

\section{Descriptive results}

Table 1 shows that there were significant differences between adults to access health care in each region. Table 1 shows that the average adult in Indonesia who uses the hospital is around 3\%. The highest proportion is in Papua (3.9\%), while the lowest proportion is in Sumatra (2.2\%). The average age of the respondents was also different across regions Table 1. Papua region has the youngest average age (36.64), while Java-Bali region has the oldest average age (41.90). The composition of the population in each region is dominated by those who live in rural areas, except in the Java-Bali region. Based on gender, all regions are dominated by women, except in the Papua region.

In general, Table 1 shows the dominance of married people compared to single and divorce in all regions. The level of adult education in Indonesia is still dominated by those with elementary school education and below, with the highest percentage in the Nusa Tenggara region (56.8\%). Based on the type of work, it is dominated by those who do not work, with the highest proportion in the Sulawesi region $(47.0 \%)$. Socioeconomically some regions show composition with wide gaps. In the Papua region, for example, quintile 1 (very poor) was $55.4 \%$, while those in quintile 5 were very rich at only $8.1 \%$. Unlike the Sumatra region, the population of quintile 1 is only $15.1 \%$, while quintile 5 has $27.8 \%$. In the average insurance, ownership variable that does not have insurance is below $50 \%$. The lowest is in the region of Papua, which only has $29.9 \%$ of the population who are uninsured or having private insurance.

\section{Multivariate regression analyses}

We performed a multinomial logistic regression test to detect disparity in hospital utilization between regions in Indonesia (Table 2.) As a reference, the category "no utilization" was chosen. Table 2 shows clear disparities between regions in Indonesia. The Papua region was chosen as a reference as it showed the best utilization of hospitals in the outpatient category. The closest region is Java-Bali, which has the possibility of utilizing hospital versus outpatient facilities. No hospital use 0.401 times occurs in adults in the Java-Bali region compared to the Papua region $(\mathrm{OR}=0.401 ; 95 \% \mathrm{Cl}=0.368-0.439)$. In the multivariate analysis, sex showed significant association with disparities in the utilization of inpatient and outpatients services by the population while age is not showed any significant correlation.

In the inpatient category, all regions have better utilization than the Papua region, except the Sumatra region, while the Kalimantan region although has a smaller OR is not meaningful (insignificant). The highest disparity occurs between the Nusa Tenggara region and the Papua region. Possibility of utilizing hospital versus inpatient facilities not using the hospital 1439 times in adults in the Nusa Tenggara region compared to the Papua region $(\mathrm{OR}=1.439 ; 95 \% \mathrm{Cl}=1.271-1.629)$. In the category of outpatient utilization as well as hospitalization in hospitals, the Papua region has better hospital utilization compared to other regions. The greatest disparity with the Sumatra region $(\mathrm{OR}=0.484 ; 95 \% \mathrm{Cl}=0.392-0.597)$. Table 2 also shows the disparities that occur in other categories. In all categories of hospital utilization, urban areas have better utilization than rural as a reference. Women have better utilization in the inpatient category than men, but in the category of outpatient utilization as well as hospitalization occur otherwise.

In the marital status category, those who were married were slightly better than those who were divorced in the outpatient utilization in the hospital $(\mathrm{OR}=1.092 ; 95 \% \mathrm{Cl}=1.006-1.185)$. In the category of inpatient utilization, those who were not married had lower utilization compared to those who received treatment $(\mathrm{OR}=0.757 ; 95 \% \mathrm{Cl}=0.688-0.834)$. While in the category of outpatient utilization as well as hospitalization in their hospitals, the marriage has the possibility of using 1230 times compared to the divorce. 
Table 1: Descriptive statistics

\begin{tabular}{|c|c|c|c|c|c|c|c|c|c|}
\hline \multirow[t]{2}{*}{ Characteristic } & \multicolumn{7}{|l|}{$\begin{array}{l}\text { Region, } \\
n(\%)\end{array}$} & \multirow[t]{2}{*}{ All } & \multirow[t]{2}{*}{$p$} \\
\hline & Sumatera & Java-Bali & Nusa Tenggara & Kalimantan & Sulawesi & Maluku Islands & Papua & & \\
\hline Hospital utility & & & & & & & & & $<0.001^{*}$ \\
\hline Outpatient & $1.867(0.9 \%)$ & $3.262(1.3 \%)$ & $374(0.9 \%)$ & $575(0.8 \%)$ & $777(0.8 \%)$ & $218(1.0 \%)$ & $699(2.3 \%)$ & $7.772(1.1 \%)$ & \\
\hline Inpatient & $2.470(1.1 \%)$ & $4.794(1.9 \%)$ & $806(1.9 \%)$ & 975 (1.4\%) & $2.037(2.2 \%)$ & $325(1.5 \%)$ & $375(1.2 \%)$ & $11.782(1.6 \%)$ & \\
\hline Outpatient + inpatient & $530(0.2 \%)$ & $1.065(0.4 \%)$ & $104(0.2 \%)$ & $165(0.2 \%)$ & $253(0.3 \%)$ & $48(0.2 \%)$ & $111(0.4 \%)$ & $2.276(0.3 \%)$ & \\
\hline No utilization & $212.293(97.8 \%)$ & $237.135(96.3 \%)$ & $41.839(97.0 \%)$ & $67.328(97.5 \%)$ & $91.029(96.7 \%)$ & $21.440(97.3 \%)$ & $29.435(96.1 \%)$ & $700.499(97.0 \%)$ & \\
\hline Age (mean) & 217,160 (38.59) & $246,256(41.90)$ & $43,123(39.60)$ & $69,043(38.65)$ & $94,096(40.22)$ & $22,031(38.75)$ & $30,620(36.64)$ & 722,329 (39.92) & $<0.001^{*}$ \\
\hline Area & & & & & & & & & $<0.001^{*}$ \\
\hline Urban & $91.263(42.0 \%)$ & $145.984(59.3 \%)$ & $15.238(35.3 \%)$ & $30.048(43.5 \%)$ & $35.304(37.5 \%)$ & $8.383(38.1 \%)$ & $7.511(24.5 \%)$ & $333.731(46.2 \%)$ & \\
\hline Rural (Ref.) & $125.897(58.0 \%)$ & $100.272(40.7 \%)$ & $27.885(64.7 \%)$ & $38.995(56.5 \%)$ & $58.792(62.5 \%)$ & $13.648(61.9 \%)$ & $23.109(75.5 \%)$ & $388.598(53.8 \%)$ & \\
\hline Gender & & & & & & & & & $<0.001^{*}$ \\
\hline Male & $106.349(49.0 \%)$ & $117.024(47.5 \%)$ & $20.343(47.2 \%)$ & $33.900(49.1 \%)$ & $44.295(47.1 \%)$ & $10.355(47.0 \%)$ & $15.557(50.8 \%)$ & $347.823(48.2 \%)$ & \\
\hline Female (Ref.) & $110.811(51.0 \%)$ & $129.232(52.5 \%)$ & $22.780(52.8 \%)$ & $35.143(50.9 \%)$ & $49.801(52.9 \%)$ & $11.676(53.0 \%)$ & $15.063(49.2 \%)$ & $374.506(51.8 \%)$ & \\
\hline Marital status & & & & & & & & & $<0.001^{*}$ \\
\hline Single & $57.209(26.3 \%)$ & $50.616(20.6 \%)$ & $11.134(25.8 \%)$ & $14.872(21.5 \%)$ & $22.035(23.4 \%)$ & $5.201(23.6 \%)$ & $5.668(18.5 \%)$ & $166.735(23.1 \%)$ & \\
\hline Married & $144.956(66.8 \%)$ & $172.258(70.0 \%)$ & $29.257(67.8 \%)$ & $49.280(71.4 \%)$ & $64.120(68.1 \%)$ & $15.499(70.4 \%)$ & $23.392(76.4 \%)$ & $498.762(69.0 \%)$ & \\
\hline Divorce/widowed (Ref.) & $14.995(6.9 \%)$ & $23.382(9.5 \%)$ & $2.732(6.3 \%)$ & $4.891(7.1 \%)$ & $7.941(8.4 \%)$ & $1.331(6.0 \%)$ & $1.560(5.1 \%)$ & $56.832(7.9 \%)$ & \\
\hline Education level & & & & & & & & & $<0.001^{*}$ \\
\hline Under primary school & $91.540(42.2 \%)$ & $126.767(51.5 \%)$ & $24.486(56.8 \%)$ & $34.399(49.8 \%)$ & $45.350(48.2 \%)$ & $9.520(43.2 \%)$ & $16.691(54.5 \%)$ & $348.753(48.3 \%)$ & \\
\hline Junior high school & $49.179(22.6 \%)$ & $47.670(19.4 \%)$ & $7.323(17.0 \%)$ & $14.136(20.5 \%)$ & $19.067(20.3 \%)$ & $4.832(21.9 \%)$ & $5.449(17.8 \%)$ & $147.656(20.4 \%)$ & \\
\hline Senior high school & $61.002(28.1 \%)$ & $55.569(22.6 \%)$ & $8.563(19.9 \%)$ & $15.866(23.0 \%)$ & $22.079(23.5 \%)$ & $5.881(26.7 \%)$ & $6.389(20.9 \%)$ & $175.349(24.3 \%)$ & \\
\hline College (Ref.) & $15.439(7.1 \%)$ & $16.250(6.6 \%)$ & $2.751(6.4 \%)$ & $4.642(6.7 \%)$ & $7.600(8.1 \%)$ & $1.798(8.2 \%)$ & $2.091(6.8 \%)$ & $50.571(7.0 \%)$ & \\
\hline Work type & & & & & & & & & $<0.001^{*}$ \\
\hline No work & $87.676(40.4 \%)$ & $96.555(39.2 \%)$ & $15.413(35.7 \%)$ & $26.934(39.0 \%)$ & $44.266(47.0 \%)$ & $9.957(45.2 \%)$ & $11.178(36.5 \%)$ & $291.979(40.4 \%)$ & \\
\hline Public servant/army/police & $10.281(4.7 \%)$ & $7.256(2.9 \%)$ & $2.024(4.7 \%)$ & $3.842(5.6 \%)$ & $5.233(5.6 \%)$ & $1.631(7.4 \%)$ & $2.263(7.4 \%)$ & $32.530(4.5 \%)$ & \\
\hline Employee & $11.206(5.2 \%)$ & $26.428(10.7 \%)$ & $1.547(3.6 \%)$ & $5.932(8.6 \%)$ & $3.249(3.5 \%)$ & $618(2.8 \%)$ & $1.101(3.6 \%)$ & $50.081(6.9 \%)$ & \\
\hline Entrepreneur & $29.243(13.5 \%)$ & $35.663(14.5 \%)$ & $3.677(8.5 \%)$ & $10.384(15.0 \%)$ & $10.141(10.8 \%)$ & $1.802(8.2 \%)$ & $2.220(7.3 \%)$ & $93.130(12.9 \%)$ & \\
\hline Farmer/fisherman/labor & $70.593(32.5 \%)$ & $71.739(29.1 \%)$ & $18.167(42.1 \%)$ & $18.956(27.5 \%)$ & $25.575(27.2 \%)$ & $6.921(31.4 \%)$ & $12.693(41.5 \%)$ & $224.644(31.1 \%)$ & \\
\hline Others (Ref.) & $8.161(3.8 \%)$ & $8.615(3.5 \%)$ & $2.295(5.3 \%)$ & $2.995(4.3 \%)$ & $5.632(6.0 \%)$ & $1.102(5.0 \%)$ & $1.165(3.8 \%)$ & $29.965(4.1 \%)$ & \\
\hline Socioeconomic status & & & & & & & & & $<0.001^{*}$ \\
\hline Quintile 1 & $32.815(15.1 \%)$ & $27.421(11.1 \%)$ & $17.534(40.7 \%)$ & $11.971(17.3 \%)$ & $19.136(20.3 \%)$ & $6.901(31.1 \%)$ & $16.969(55.4 \%)$ & $132.747(18.4 \%)$ & \\
\hline Quintile 2 & $38.790(17.9 \%)$ & $47.131(19.1 \%)$ & $10.812(25.1 \%)$ & $12.497(18.1 \%)$ & $19.611(20.8 \%)$ & $5.786(26.3 \%)$ & $5.026(16.4 \%)$ & $139.653(19.3 \%)$ & \\
\hline Quintile 3 & $40.274(18.5 \%)$ & $61.534(25.0 \%)$ & $6.610(15.3 \%)$ & $13.493(19.5 \%)$ & $17.604(18.7 \%)$ & $4.170(18.9 \%)$ & $3.089(10.1 \%)$ & $146.774(20.3 \%)$ & \\
\hline Quintile 4 & $44.952(20.7 \%)$ & $61.877(25.1 \%)$ & $5.277(12.2 \%)$ & $13.625(19.7 \%)$ & $18.787(20.0 \%)$ & $3.812(17.3 \%)$ & $3.062(10.0 \%)$ & $151.392(21.0 \%)$ & \\
\hline Quintile 5 (Ref.) & $60.329(27.8 \%)$ & $48.293(19.6 \%)$ & $2.890(6.7 \%)$ & $17.457(25.3 \%)$ & $18.958(20.1 \%)$ & $1.362(6.2 \%)$ & $2.474(8.1 \%)$ & $151.763(21.0 \%)$ & \\
\hline Insurance & & & & & & & & & $<0.001^{*}$ \\
\hline $\begin{array}{l}\text { No insurance or private } \\
\text { insurance (Ref.) }\end{array}$ & $100.262(46.2 \%)$ & $129.830(52.7 \%)$ & $15.241(35.3 \%)$ & $35.015(50.7 \%)$ & $29.684(31.5 \%)$ & $9.543(43.3 \%)$ & $9.176(29.9 \%)$ & $328.752(45.5 \%)$ & \\
\hline $\begin{array}{l}\text { Insured by government } \\
\text { (Askes, Jamkesmas, } \\
\text { Jamkesda, Jamsostek) }\end{array}$ & $116.897(53.8 \%)$ & $116.426(47.3 \%)$ & $27.882(64.7 \%)$ & $34.028(49.3 \%)$ & $64.412(68.5 \%)$ & $12.488(56.7 \%)$ & $21.444(70.0 \%)$ & $393.577(54.5 \%)$ & \\
\hline
\end{tabular}

Table 2 also shows that better education (college) has better hospital utilization in all categories. In the type of work category, those who do not work have better utilization than those who work in other categories in all categories of hospital utilization. Meanwhile in the socioeconomic status category, Table 2 shows information that the better the socioeconomic status, the better the utilization of hospital services. This condition applies to all categories of hospital utilization.

\section{Discussion}

The results of this study indicate that there are disparities between regions in Indonesia. This condition is in line with several other studies on the disparity of the region. A study conducted to identify the existence of disparity in outcomes in patients with peripheral artery disease in the United States found that variations in regions contribute to differences in outcomes over the long term [13]. Another study conducted to identify disparities between regions in the level of cesarean section also produced the same conclusions. Studies conducted in 28 countries found significant regional disparities. Disparities between regions are estimated due to a combination of inadequate access to emergency obstetric services. Another reason is likely because of the high rate of caesarean section without medical indications in the richest subgroups [14].

Studies conducted to look at regional disparities in interhospital referrals in mechanically ventilated patients with sepsis found significant differences in geographical location. The study also found racial differences as other disparities. The researcher explained that this study did not explain the medical diagnosis or the severity of the patient's disease [11]. The study of other disparities was carried out in America to see home care services for geriatrics in America. The study found that residents in regions that are economically disadvantaged experience inequalities in accessing nursing homes with higher star ratings. These areas may lack sufficient resources for adequate facility staff and provide treatments that meet industry quality standards [15]. The same research results were found in Slovakia. This study was conducted to test the localization parameters selected in the distribution and use of medical equipment. The results are needed to verify the potential for regional differences. The study found significant regional disparities [16]. The Papua region including other eastern part of Indonesia was known to have lack of health-care development [17], [18]. The Public Health Development index in this region was the lowest in the country [19]. This health-care divide between western and eastern part of Indonesia made the current government strive to improve the health care and facilities in Papua regions. Some of the government program to accelerate health-care access in East Indonesia include training for human resources, physical renovation and building new hospitals, flying doctor, and also floating hospital [17], [18].

While studies in Sweden found no disparity between regions, this study was conducted to assess 
Table 2: Multinomial logistic regression of Indonesia adults hospital utilization using RKD 2013 data

\begin{tabular}{|c|c|c|c|c|c|c|c|c|c|}
\hline \multirow[t]{2}{*}{ Predictor } & \multicolumn{3}{|c|}{ Outpatient } & \multicolumn{3}{|c|}{ Inpatient } & \multicolumn{3}{|c|}{ Outpatient + Inpatient } \\
\hline & OR & Upper bound & Lower bound & OR & Upper bound & Lower bound & OR & Upper bound & Lower bound \\
\hline Age & $1.029^{*}$ & 1.027 & 1.031 & $1.015^{*}$ & 1.013 & 1.016 & $1.032^{\star}$ & 1.029 & 1.036 \\
\hline Region: Sumatera & $0.273^{*}$ & 0.249 & 0.300 & $0.717^{\star}$ & 0.641 & 0.801 & $0.484^{*}$ & 0.392 & 0.597 \\
\hline Region: Java-Bali & $0.401^{*}$ & 0.368 & 0.439 & $1.178^{*}$ & 1.056 & 1.313 & 0.821 & 0.670 & 1.005 \\
\hline Region: Nusa Tenggara & $0.354^{*}$ & 0.312 & 0.403 & $1.439^{*}$ & 1.271 & 1.629 & $0.622^{*}$ & 0.475 & 0.814 \\
\hline Region: Kalimantan & $0.277^{*}$ & 0.247 & 0.311 & 0.907 & 0.803 & 1.025 & $0.499^{*}$ & 0.391 & 0.638 \\
\hline Region: Sulawesi & $0.249^{*}$ & 0.224 & 0.277 & $1.304^{*}$ & 1.165 & 1.459 & $0.485^{*}$ & 0.386 & 0.608 \\
\hline Region: Maluku & $0.374^{*}$ & 0.321 & 0.437 & 1.052 & 0.905 & 1.223 & $0.513^{\star}$ & 0.365 & 0.722 \\
\hline Area: Urban & $1.410^{*}$ & 1.335 & 1.489 & $1.181^{*}$ & 1.132 & 1.232 & $1.259^{\star}$ & 1.142 & 1.389 \\
\hline Gender: Male & 0.964 & 0.917 & 1.015 & $0.935^{*}$ & 0.896 & 0.975 & $1.210^{*}$ & 1.100 & 1.330 \\
\hline Marital status: single & 1.023 & 0.908 & 1.153 & $0.757^{\star}$ & 0.688 & 0.834 & 0.899 & 0.717 & 1.127 \\
\hline Marital status: Married & $1.092^{*}$ & 1.006 & 1.185 & 1.014 & 0.949 & 1.084 & $1.230^{*}$ & 1.062 & 1.425 \\
\hline Education: Under primary school & $0.556^{*}$ & 0.507 & 0.609 & $0.788^{*}$ & 0.726 & 0.854 & $0.672^{*}$ & 0.565 & 0.800 \\
\hline Education: Junior high school & $0.743^{*}$ & 0.676 & 0.816 & $0.839^{*}$ & 0.772 & 0.912 & 0.908 & 0.760 & 1.084 \\
\hline Education: Senior high school & $0.849^{*}$ & 0.784 & 0.920 & $0.884^{*}$ & 0.820 & 0.952 & 0.935 & 0.800 & 1.093 \\
\hline Work: No work & $1.238^{*}$ & 1.101 & 1.392 & $1.215^{\star}$ & 1.108 & 1.331 & $1.416^{\star}$ & 1.148 & 1.745 \\
\hline Work: Public servant/army/police & 1.128 & 0.982 & 1.296 & 0.932 & 0.827 & 1.051 & 0.824 & 0.633 & 1.072 \\
\hline Work: Employee & $1.073^{*}$ & 0.937 & 1.228 & 0.927 & 0.829 & 1.036 & $0.766^{*}$ & 0.594 & 0.988 \\
\hline Work: Entrepreneur & $0.838^{*}$ & 0.736 & 0.954 & $0.850^{*}$ & 0.768 & 0.941 & $0.734^{*}$ & 0.580 & 0.928 \\
\hline Work: Farmer/fisherman/labor & $0.769^{*}$ & 0.677 & 0.872 & $0.760^{*}$ & 0.689 & 0.838 & $0.610^{*}$ & 0.486 & 0.767 \\
\hline Socioeconomic: Quintile 1 & $0.494^{*}$ & 0.448 & 0.545 & $0.507^{\star}$ & 0.468 & 0.548 & $0.420^{*}$ & 0.349 & 0.506 \\
\hline Socioeconomic: Quintile 2 & $0.549^{*}$ & 0.504 & 0.598 & $0.700^{*}$ & 0.655 & 0.747 & $0.581^{*}$ & 0.500 & 0.676 \\
\hline Socioeconomic: Quintile 3 & $0.697^{*}$ & 0.649 & 0.749 & $0.824^{*}$ & 0.777 & 0.873 & $0.681^{*}$ & 0.597 & 0.777 \\
\hline Socioeconomic: Quintile 4 & $0.852^{*}$ & 0.801 & 0.907 & $0.946^{*}$ & 0.898 & 0.997 & $0.885^{*}$ & 0.791 & 0.991 \\
\hline Insurance: No insurance or private insurance (others) & $0.290^{*}$ & 0.262 & 0.321 & $0.466^{*}$ & 0.423 & 0.514 & $0.252^{*}$ & 0.208 & 0.305 \\
\hline $\begin{array}{l}\text { Insurance: Government insurance (Askes, } \\
\text { Jamkesmas, Jamkesda, Jamsostek) }\end{array}$ & $0.617^{*}$ & 0.561 & 0.679 & $0.729^{*}$ & 0.662 & 0.802 & $0.620^{*}$ & 0.518 & 0.740 \\
\hline
\end{tabular}

The reference category is "No Utilization," 95\% confidence interval for OR. *Significant at level 95\%.

differences in gallstone surgery regarding antibiotic use in Sweden. This study was conducted to assess differences in gallstone surgery regarding antibiotic use in Sweden. Significant disparities were found only between hospitals and surgeons [20]. Health service utilization is influenced not only because of the distribution of health service facilities in the region but also influenced by human distribution and supporting environment, which influence decision-making and behavior in relation to service utilization [21].

Understanding the etiology of regional disparity in health services is very important to improve services for all people. Analysis of disparities between regions can be used by each region to improve the quality of their services [13], [16]. In Korea, health service disparities are recognized in facilities, equipment, and neonatal health outcomes. Although the number of highrisk neonates has increased in Korea, hospitals are reluctant to open neonatal intensive care units because of low medical costs. Finally, the Korean government is investing in deficiencies whose information is generated from previous regional disparity studies.

The results show the difference in odds ratio for mortality between regions decreased compared to the previous period. There is an increase in regional differences in neonatal care and mortality of premature infants with government investment in Korea [22]. Another way to increase the coverage of health service utilization is in a proactive manner. Officers can make home visits for health care, especially in elderly patients [23].

There are some limitations in this study including the complex survey design that should be accounted for adjustment through weighting for example. Hence, the results of our study might be subjected to selection bias. Having said that, with large sample size and nationally represented data, we believed that the bias was minimized. Furthermore, the limitation of this study was related to the use of secondary data that were limited and superficial in answering the complex phenomenon of health disparities. Hence, large primary data collection is warranted for better quality of data describing the health inequality in Indonesia.

\section{Conclusions}

Disparities in hospital utilization among regions in Indonesia were associated with complex factors including marital status, socioeconomic status, education level, occupation, and insurance ownership. However, the difference in odds ratio for mortality between regions decreased compared to the previous period. Based on our study, we believed that to bridging the gap and decrease disparities among regions, the government should accelerate the development of health-care facilities, especially in regions that live in rural area, widowed, low educated, poor, and uninsured or having private insurance. Government insurance with subsidy and the program for universal coverage should be implemented nationwide to improve access for all citizens.

\section{Authors' Contributions}

ADL was responsible for overall and/or sectional scientific management, formulating research question, making concept and design of the study, preparation of draft manuscript, and doing revisions. He also gave final approval of the version to be published; and agreed to 
be accountable for all aspects of the work in ensuring that questions related to the accuracy or integrity of any part of the work are appropriately investigated and resolved. ADL was responsible for data input, cleaning, and initial analysis. TM was responsible for substantial contributions in design and conception of the study, and was involved in manuscript preparation, providing critique, revision of the manuscript, and analyzed the finding. BB was responsible for data interpretation and analysis. BB also did the revision of the manuscript throughout the process. All authors have given approval of the final manuscript.

\section{Acknowledgments}

The authors would like to acknowledge the contribution of Ms. Calista Segalita and Ms. Kus Amira for manuscript revision.

\section{References}

1. Laksono AD. Aksesibilitas Pelayanan Kesehatan. Aksesibilitas Pelayanan Kesehatan di Indonesia; 2016. p. 5-20.

2. Kenea $\mathrm{D}$, Jisha $\mathrm{H}$. Urban-rural disparity and determinants of delivery care utilization in Oromia region, Ethiopia: Communitybased cross-sectional study. Int J Nurs Pract. 2017;23(1):12510. http://doi.org/10.1111/ijn.12510

PMid:28090752

3. Loree JM, Javaheri KR, Lefresne SV, Speers CH, Ruan JY, Chang JT, et al. Impact of travel distance and urban-rural status on the multidisciplinary management of rectal cancer. J Rural Health. 2017;33(4):393-401. http://doi.org/10.1111/jrh.12219 PMid:27717002

4. Dorjdagva J, Batbaatar E, Svensson M, Dorjsuren B, Batmunkh B, Kauhanen J. Free and universal, but unequal utilization of primary health care in the rural and urban areas of Mongolia. Int J Equity Health. 2017;16(1):73. http://doi. org/10.1186/s12939-017-0572-4

5. Wen PC, Lee C, Chang YH, Ku LJ, Li CY. Demographic and rural-urban variations in dental service utilization in Taiwan. Rural Remote Health. 2017;17(3):4161. http://doi.org/10.22605/ $\mathrm{RRH} 4161$

PMid:28838246

6. Chiang CL, Chen PC, Huang LY, Kuo PH, Tung YC, Liu CC, et al. Impact of universal health coverage on urban-rural inequity in psychiatric service utilisation for patients with first admission for psychosis: A 10-year nationwide population-based study in Taiwan. Br Med J. 2016;6(3):e010802. http://doi.org/10.1136/ bmjopen-2015-010802

PMid:26940114

7. Gonzales S, Mullen MT, Skolarus L, Thibault DP, Udoeyo U, Willis AW. Progressive rural-urban disparity in acute stroke care. Neurology. 2017;88(5):441-8. http://doi.org/10.1212/ WNL.0000000000003562

PMid:28053009
8. Galal SB, Al-Gamal N. Health problems and the health care provider choices: A comparative study of urban and rural households in Egypt. J Epidemiol Glob Health. 2014;4(2):141-9. https://dx.doi.org/10.1016/j.jegh.2013.12.002

PMid:24857182

9. Sheikh K. Utility of provider volume as an indicator of medical care quality and for policy decisions. Am J Med. 2001;111(9):712-5. http://doi.org/10.1016/s0002-9343(01)00924-x PMid:11747851

10. Elayyat $A H$, Sadek A. Hospital utilization pattern in a hepatogastroenterology department of a research institute hospital, from 2004 to 2013. J Egypt Public Health Assoc. 2016;91(2):59-64. http://doi.org/10.1097/01. EPX.0000482537.88140.0c PMid:27455082

11. Tyler PD, Stone DJ, Geisler BP, McLennan S, Celi LA, Rush B. Racial and geographic disparities in interhospital ICU transfers. Crit Care Med. 2018;46(1):76-80. http://doi.org/10.1097/ CCM.0000000000002776 PMid:29068859

12. Riskesdas. Riset Kesehatan Dasar (RISKESDAS) 2013. Laporan Nasional; 2013. p. 1-384.

13. O'Donnell TF, Powell C, Deery SE, Darling JD, Hughes K, Giles KA, et al. Regional variation in racial disparities among patients with peripheral artery disease. J Vasc Surg. 2018;68(2):519-26. http://doi.org/10.1016/j.jvs.2017.10.090 PMid:29459014

14. Boatin AA, Schlotheuber A, Betran AP, Moller AB, Barros AJ, Boerma $\mathrm{T}$, et al. Within country inequalities in caesarean section rates: Observational study of 72 low and middle income countries. Br Med J. 2018;360:k55. http://doi.org/10.1136/bmj. k55

PMid:29367432

15. Finucane MM, Stevens GA, Cowan M, Lin JK, Paciorek CJ, Singh GM, et al. HHS Public Access Participants. Vol. 377. 2015. p. 557-67.

16. Gavurová B, Kováč V, Fedačko J. Regional disparities in medical equipment distribution in the Slovak Republic a platform for a health policy regulatory mechanism. Health Econ Rev. 2017;7(1):39. http://doi.org/10.1186/s13561-017-0176-0 PMid:29124432

17. Laksono AD, Wulandari RD, Soedirham O. Regional disparities of health center utilization in rural Indonesia. Malaysian J Public Health Med. 2019;19(1):158-66.

18. Laksono AD, Wulandari RD, Soedirham O. Urban and rura disparities in hospital utilization among Indonesian adults. Iran J Public Health. 2019;48(2):247-55.

PMid:31205878

19. National Institute of Health Research and Development of Ministry of Health of the Republic of Indonesia. The 2018 Indonesia Basic Health Survey (Riskesdas). Jakarta: National Report. Available from: https://kesmas.kemkes.go.id/assets/ upload/dir_519d41d8cd98f00/files/Hasil-riskesdas-2018_1274. pdf

20. Jaafar G, Darkahi B, Lindhagen L, Persson G, Sandblom G. Disparities in the regional, hospital and individual levels of antibiotic use in gallstone surgery in Sweden. BMC Surg. 2017;17(1):128. http://doi.org/10.1186/s12893-017-0312-0.

21. Ryvicker, M. A conceptual framework for examining healthcare access and navigation: A behavioral-ecological perspective. Soc Theory Health. 2018;16(3):224-40. http://doi.org/10.1057/ s41285-017-0053-2

PMid:31007612

22. Song IG, Shin SH, Kim HS. Improved regional disparities in 
neonatal care by government-led policies in korea. J Korean Med Sci. 2018;33(6):e43. http://doi.org/10.3346/jkms.2018.33.e43 PMid:29349938

23. Chung S, Romanelli RJ, Stults CD, Luf HS. Preventive visit among older adults with medicare's introduction of annual wellness visit: Closing gaps in underutilization. Prev Med. 2018;115:110-8. http://doi.org/10.1016/j.ypmed.2018.08.018

PMid:30145346 